\title{
INTEGRATION OF RESOURCE RECOVERY INTO CURRENT WASTE MANAGEMENT THROUGH (ENHANCED) LANDFILL MINING
}

\author{
Juan Carlos Hernández Parrodi 1,2,, , Hugo Lucas ${ }^{3}$, Marco Gigantino ${ }^{4}$, Giovanna Sauve 5 , \\ John Laurence Esguerra ${ }^{6,7}$, Paul Einhäupl 5,7, Daniel Vollprecht ${ }^{2}$, Roland Pomberger ${ }^{2}$, \\ Bernd Friedrich ${ }^{3}$, Karel Van Acker ${ }^{5}$, Joakim Krook ${ }^{6}$, Niclas Svensson ${ }^{6}$ and Steven Van \\ Passel ${ }^{7}$
}

${ }^{1}$ Renewi Belgium SA/NV, NEW-MINE project, 3920 Lommel, Belgium

${ }^{2}$ Montanuniversität Leoben, Department of Environmental and Energy Process Engineering, 8700 Leoben, Austria

${ }^{3}$ RWTH Aachen University, Process Metallurgy and Metal Recycling, 52056 Aachen, Germany

${ }^{4}$ ETH Zürich, Department of Mechanical and Process Engineering, 8092 Zürich, Switzerland

${ }^{5}$ Katholieke Universiteit Leuven, Department of Materials Engineering, 3001 Leuven, Belgium

${ }^{6}$ Linköping University, Environmental Technology and Management, 58183 Linköping, Sweden

${ }^{7}$ Universiteit Antwerpen, Department of Engineering Management, 2000 Antwerpen, Belgium

Article Info:

Received:

1 November 2019

Accepted:

15 November 2019

Available online:

23 December 2019

Keywords:

Landfill mining strategies

Enhanced landfill mining

Resource recovery

Waste management practices and

policies

Economic assessment

Environmental impacts

\section{ABSTRACT}

Europe has somewhere between 150,000 and 500,000 landfill sites, with an estimated $90 \%$ of them being "non-sanitary" landfills, predating the EU Landfill Directive of 1999/31/EC. These older landfills tend to be filled with municipal solid waste and often lack any environmental protection technology. "Doing nothing", state-of-theart aftercare or remediating them depends largely on technical, societal and economic conditions which vary between countries. Beside "doing nothing" and landfill aftercare, there are different scenarios in landfill mining, from re-landfilling the waste into "sanitary landfills" to seizing the opportunity for a combined resource-recovery and remediation strategy. This review article addresses present and future issues and potential opportunities for landfill mining as an embedded strategy in current waste management systems through a multi-disciplinary approach. In particular, three general landfill mining strategies are addressed with varying extents of resource recovery. These are discussed in relation to the main targets of landfill mining: (i) reduction of the landfill volume (technical), (ii) reduction of risks and impacts (environmental) and (iii) increase in resource recovery and overall profitability (economic). Geophysical methods could be used to determine the characteristics of the landfilled waste and subsurface structures without the need of an invasive exploration, which could greatly reduce exploration costs and time, as well as be useful to develop a procedure to either discard or select the most appropriate sites for (E)LFM. Material and energy recovery from landfilled waste can be achieved through mechanical processing coupled with thermochemical valorization technologies and residues upcycling techniques. Gasification could enable the upcycling of residues after thermal treatment into a new range of eco-friendly construction materials based on inorganic polymers and glass-ceramics. The multi-criteria assessment is directly influenced by waste- and technology related factors, which together with site-specific conditions, market and regulatory aspects, influence the environmental, economic and societal impacts of (E)LFM projects.

\section{INTRODUCTION}

From the very beginning of the development of human settlements and the accumulation of residues discarded by their inhabitants, certain places, known today as landfills, have been created for the disposal of waste. Prior to the 1950s, those sites were mostly wild dumpsites in which environmental, health and safety implications were not taken into account, making them critical sources of pollution and posing a threat to the environment (Meegoda et al., 2016).

Research carried out over the last decades as well as growing public awareness have led to modern guidelines and regulations (Meegoda et al., 2016), with an increasing 
tendency for the implementation of an integrated waste management system into a circular economy. However, the role of the landfill in a modern waste management system as an ultimate sink for contaminants is still valid (Brunner, 2004). Nowadays it is well known that landfilled waste undergoes several degradation processes during a long period of time, and with negative environmental implications (Belevi \& Baccini, 1989; Bozkurt et al., 1999; Martensson et al., 1999). Leaching of heavy metals and other toxic compounds to soil, surface- and groundwater, gas emissions, such as $\mathrm{SO}_{2}, \mathrm{CH}_{4}, \mathrm{CO}_{2}$, surface runoff, windblown litter and dust, and proliferation of birds, vermin and insects are among the most common negative environmental and health effects of waste landfilling (Höxter, 2001), if landfill gas and leachate are not properly managed.

Contemporary landfills, known as "sanitary landfills" (Figure 1) are engineered disposal sites designed to minimize adverse environmental and health impacts, while higher safety measures are imposed and the storage of waste is enhanced (e.g. waste compaction and conformation) (EU Landfill Directive 1999/31/EC). Before depositing waste in a sanitary landfill, the place destined to become such a disposal site is carefully selected and its base is covered by a number of protection barriers (e.g. a layer of compacted clay, asphalt and/or synthetic liners), which prevent the infiltration of leachate directly into the ground and groundwater bodies. Additionally, a drainage system is placed at the bottom of the landfill basin, where a network of pipes collects the leachate generated by the disposed waste and transports it to further treatment. Waste disposed of in a landfill is also covered with a low permeabil- ity top layer to prevent infiltration of rain water, migration of gaseous emissions, windblown waste, and presence of harmful fauna. An additional pipe network is employed to collect gaseous emissions (i.e. biogas) produced during the biological decomposition of waste (Meegoda et al., 2016). Gaseous emissions, leachate, and groundwater quality in the area of the landfill site are continuously monitored in order to detect problems and, ideally, ensure that no damage is done by the landfilling of waste (Chian \& DeWalle, 1976; Meegoda et al., 2016).

However, aftercare activities (i.e. emissions monitoring and treatment and infrastructure maintenance) related to landfill sites need to be carried out over a long period of time, since the potential emissions from landfills can have significant impacts to human health and the environment for decades or even centuries (Laner et al., 2012). Over this long time period, the space used by the landfill remains occupied and unavailable for certain uses, e.g. due to insufficient geotechnical stability, which leads to paramount costs and blocked capital. Moreover, control and protection barriers in sanitary landfills may eventually fail and, alike in non-sanitary landfills or wild dumpsites, liquid, gaseous and solid emissions can be released into the environment (Laner et al., 2011b; Pivato, 2011).

Despite being an apparently low cost and relatively simple waste management disposal method, the role of waste landfilling in a circular economy model is more restricted to that of an ultimate sink of contaminants. If landfill aftercare is not conducted adequately, even contemporary landfills might represent an environmental and health hazard.

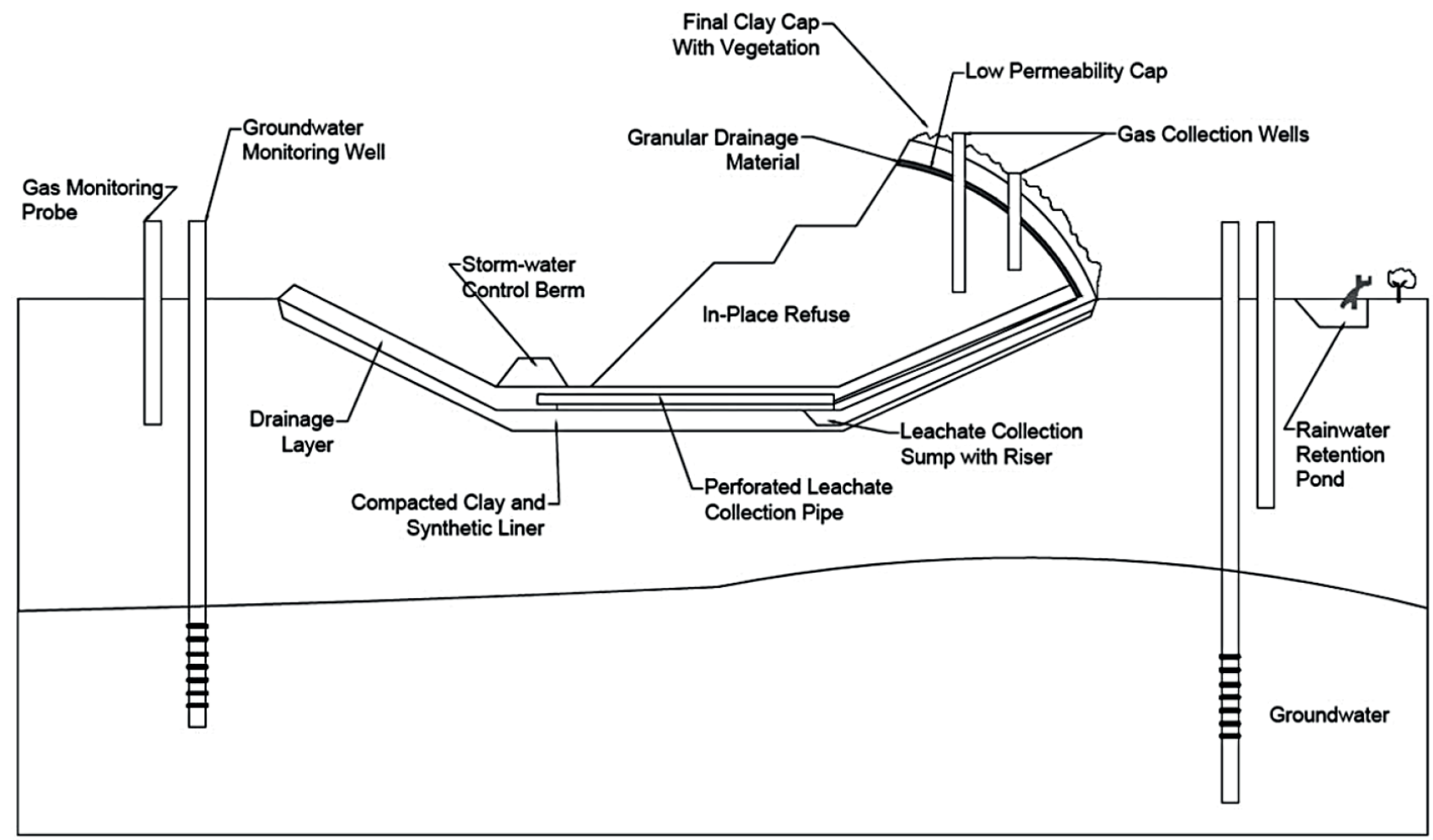

FIGURE 1: Cross-section of a contemporary sanitary landfill (Meegoda et al., 2016). 


\section{LANDFILL MINING}

The extraction of waste from disposal sites for the recovery of certain materials is far from being a novel and unprecedented concept. It is, in fact, a relatively well-known and widespread practice that has been carried out in many countries over the last six decades, which is known as landfill mining (LFM). There are several definitions of LFM; the first one was introduced by Cossu et al., 1996, in which LFM was defined as "the excavation and treatment of waste from an active or inactive landfill for one or more of the following purposes: conservation of landfill space, reduction in landfill area, elimination of a potential contamination source, mitigation of an existing contamination source, energy recovery from excavated waste, reuse of recovered materials, reduction in waste management system costs and site re-development". As defined by Krook et al., 2012 , LFM is "a process for extracting materials or other solid natural resources from waste materials that previously have been disposed of by burying them in the ground". More than half a century has passed from the beginning of LFM projects (Savage et al., 1993) and the drivers for LFM have spanned from regaining landfill capacity to recovering valuable materials, such as organic matter for soil improvement purposes, refuse derived fuel (RDF) and metals (Hogland, 2002; Prechthai et al., 2008; Savage et al., 1993; Shual, 1958; Van der Zee et al., 2004). As confirmed by Krook et al., 2012, "landfill mining has primarily been seen as a way to solve traditional management issues related to landfills such as lack of landfill space and local pollution concerns. Although most initiatives have involved some recovery of deposited resources, mainly cover-soil and in some cases waste fuel, recycling efforts have often been largely secondary".

In general terms, LFM projects have focused on expanding landfill lifetime and consolidating landfill area to facilitate the closure and remediation of those sites (Cha et al., 1997; Dickinson, 1995; Krogmann \& Qu, 1997; Spencer, 1990). The recovery of land and materials represent important drivers for LFM, together with the potential to reduce surface-, groundwater and soil contamination by remediating the landfill (Marella \& Raga, 2014). This could also contribute to the reduction of aftercare costs and other pollution-related costs. Although the mentioned factors represent important drivers for LFM, the excavation and material valorization processes could also lead to additional costs and impacts (Hermann et al., 2016). Moreover, LFM has faced great and growing challenges over time, many of them led by low amount and quality of high-value materials present in landfill sites, high costs for its implementation and increasingly stringent regulation in the waste management sector, as well as raising standards in the production industry (Krook et al., 2012).

\subsection{Scenarios of LFM}

Within the framework of the "EU Training Network for Resource Recovery through Enhanced Landfill Mining NEW-MINE" (NEW-MINE), LFM has been classified in four scenarios, namely "Do-Nothing”, "Classic remediation with relandfill", "Classic landfill mining with RDF state-of-the-art (co-)incineration" and "NEW-MINE" scenarios. The routes followed by each scenario, as well as the processes included in those routes are schematized in Figure 2.

\subsection{1 "Do-nothing" scenario}

As previously mentioned, old landfill sites or wild dumpsites have very few or no protection measures at all to prevent environmental and health damages that contemporary sanitary landfills normally have. Moreover, the containment system of sanitary landfills is likely to fail over time. Therefore, the "Do-nothing" scenario should not really be an option, since it turns a blind eye to the critical risks posed by those sites and leaves the problem unsolved indefinitely. Some basic and relatively inexpensive improvements that can be implemented in those sites could be (Höxter, 2001):

\section{Definition of dumping areas}

- Waste delivery control and documentation

- Volume reduction of disposed waste by means of waste conformation and compaction

- Aerobic pre-treatment of waste to reduce methane emission

- Installation of biogas collection system

Installation of groundwater wells for monitoring

Installation of leachate collection system (if possible)

\subsection{2 "Classic remediation with relandfill" scenario}

This scenario envisages the extraction of waste from wild dumpsites and old landfills, or problematic sanitary landfill sites, in order to place the excavated waste in a more appropriate disposal site, such as a new or contemporary sanitary landfill. For example, this can be the case due to the need to fulfill modern regulatory requirements and conventional solutions are not able to improve environmental conditions or remediate the problem (Höxter, 2001; Jones et al., 2013, 2018; Van Passel et al., 2013). According to the Flemish Public Waste Agency in Belgium, the costs for landfill remediation for the EU-28 could be as high as 100 billion to 1 trillion euros. This approach is also addressed in the initiative "Closing Dumpsites" of the International Solid Waste Association (ISWA), as the costs for re-landfilling are still far below from those of all alternatives, because the costs for processing might exceed the revenues from potentially recyclable fractions (Winterstetter et al., 2015).

\subsection{3 "Classic LFM with RDF state-of-the-art (co-)incinera- tion" scenario}

The classic LFM approach is looking not only to remediate the landfill site, but also to minimize remediation costs through the valorization of landfill waste materials. This approach has been largely applied in previous LFM projects, since it also aims to decrease the amount of waste to be re-landfilled; valorizing waste through the separation of materials with high calorific value, such as paper, plastics, textiles and wood, among others, for thermal valorization, and recyclable materials, such as metals and glass, among others, for material valorization. The thermal valorization is carried out mainly by the production of RDF, which is used in (co-)incineration plants to recover energy in the form of 


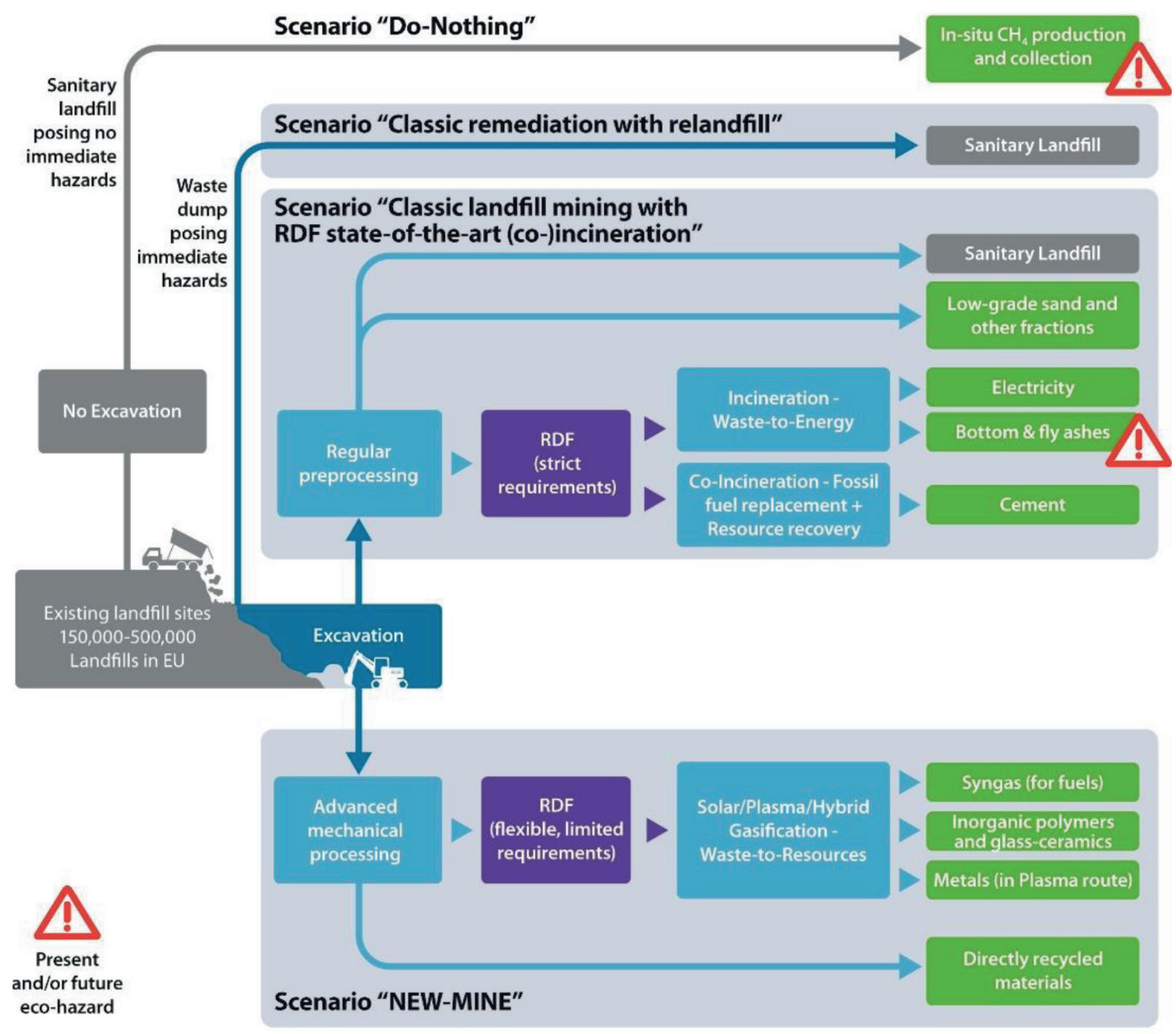

FIGURE 2: LFM scenarios (source: https://new-mine.eu).

heat and electricity (Jones et al., 2013). However, as nowadays prices for RDF are commonly negative, this scenario results less economical than the "Classic remediation with relandfill" scenario.

\subsubsection{Enhanced landfill mining or "NEW-MINE" scenario}

The need for a common framework to address LFM issues, technological development and further research on this subject has pushed scientists to develop a holistic concept called enhanced landfill mining (ELFM), which is, as defined by Jones et al., 2010, "the safe conditioning, excavation and integrated valorization of (historic and/or future) landfilled waste streams as both materials (Waste-to-Material, WtM) and energy (Waste-to-Energy, WtE), using innovative transformation technologies and respecting the most stringent social and ecological criteria", and has been under development by the Flemish ELFM Consortium since 2008 (Jones et al., 2013). To this end, the European Union's Horizon 2020 research and innovation programme within the framework of the Marie Skłodowska-Curie actions has funded the NEW-MINE project, which is referred to as "NEW-MINE" scenario in this review article. In the "NEW-MINE" scenario the technological innovation follows a value-chain approach, from advanced landfill exploration, mechanical processing, thermochemical conversion and upcycling, while the multi-criteria assessment methods compare combined resource-recovery/remediation ELFM methods with the previous scenarios: "Do-nothing", "Classic remediation with relandfill" and "Classic LFM with RDF state-of-the-art (co-)incineration". The ELFM concept or "NEW-MINE" scenario is currently under development and the main goal is to insert LFM in a circular economy context, where most of the residues are upcycled and, therefore, minimized.

\subsection{Stages in LFM}

\subsubsection{Site exploration}

The material composition and physicochemical prop- 
erties of the waste disposed of in a landfill site are the preliminary and most important information to be gathered in LFM in order to assess the economic, technical and environmental feasibility of the project. However, it is not rare that there are no records about the type or location of the waste deposited in a landfill. Hence, in the best case, LFM projects need to resort to invasive exploration by means of bore sampling or small scale excavations throughout the whole landfill site; in other cases the available disposal records are used to determine the composition and characteristics of the waste, while in the worst case, no previous analysis is done at all (Hernández Parrodi et al., 2018a). In the case of invasive exploration, the excavated waste samples are classified according to material type and particle size, which are used to determine the amount of material that might be valorized and estimate the remediation costs of the whole site (Bhatnagar et al., 2017; Cha et al., 1997; García López et al., 2019; Hernández Parrodi et al., 2018b; Hogland, 2002). However, certain fractions which might be valorized from fresh waste, may not be valorized from landfilled waste due to degradation and contamination processes in the landfill body.

From an ELFM perspective, geophysical methods, such as the ones used for underground water or petroleum exploration, could be used to determine the material characteristics in a rough manner without the need of an invasive exploration, as well as to identify the most interesting area, in terms of depth, water content and presence of certain materials, before carrying out the extraction of landfilled waste. The characterization of landfill subsurface structures using non-destructive and rapid approaches could greatly reduce the exploration costs (Bobe et al., 2018) and be useful to develop a procedure to either discard or select the most appropriate sites for LFM, according to specific criteria. For example, Figure 3 depicts the characterization of the subsurface structures of a landfill, as well as their electric and dielectric properties. These could allow the identification of the type of material to be expected according to the depth and extent of the landfill, as well as the potential presence of metallic materials and water.

\subsubsection{Excavation and material processing}

After the exploration of the site and a positive assessment of the feasibility of the site in question for LFM, the excavation of the landfilled waste takes place. This is normally done by using bulldozers to remove the top cover layers and excavators to dig out the landfilled waste. The excavated waste is usually loaded in trucks and transported to the processing plant.

Relatively simple technologies have been employed to process the excavated landfilled material, as for example trommel sieving, magnetic separation, and density classification, which in some cases have shown marginal performance in producing marketable recyclables (Krook

(a)
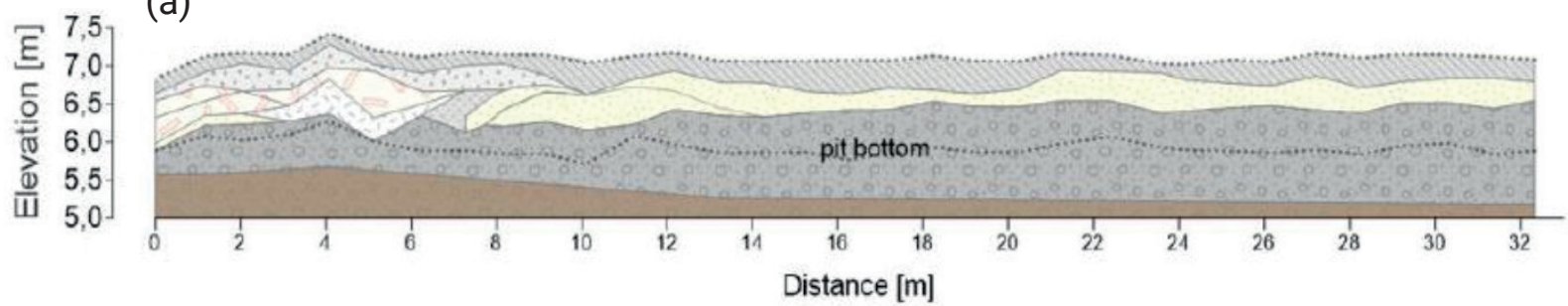

Type 1 (gravel)

Type 2 (sandy)

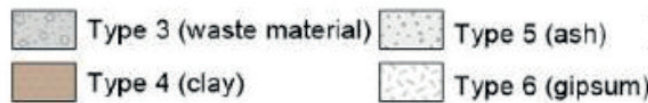

Type 7 (contains bricks)

(b)

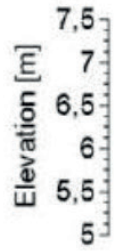

Type 6 (gipsum)
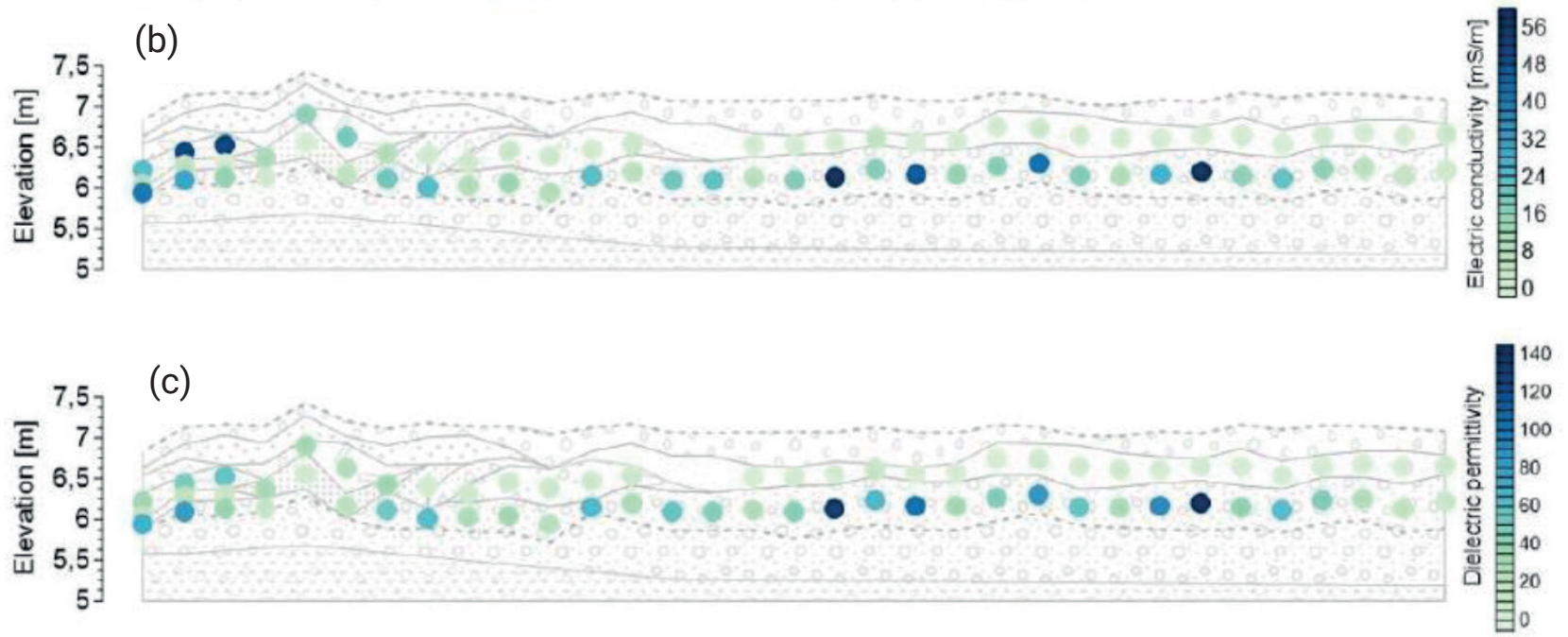

FIGURE 3: Schematic representation of the (a) profile description indicating the main types of material discriminated and (b) profile measurements of electric conductivity and (c) dielectric permittivity (Bobe et al., 2018). 
et al., 2012). Moreover, LFM has faced great and growing challenges over time, many of them led by low amount and quality of high-value materials present in landfill sites, high costs for its implementation and increasingly stringent regulation in the waste management sector, as well as raising standards in the production industry (Krook et al., 2012).

Besides the traditional techniques used in traditional LFM projects, new equipment is nowadays being tested with promising results. Ballistic separators can separate landfill waste into three different fractions, namely three-dimensional (3D) and two-dimensional (2D) materials, and an under-screen fraction. This technology can be used to pre-process the landfilled waste directly after excavation and precondition the material for further mechanical processing (García López et al., 2019). Further processing, such as drying, particle size reduction equipment, particle size classification, ferrous and non-ferrous metal separators, density separation methods and sensor-based sorting, could be employed in order to sort the landfilled waste into different material outputs (Hernández Parrodi et al., 2019b; Küppers et al., 2019), such as:

- High calorific value materials (e.g. plastics, wood, textiles, paper and cardboard, among others)

- Ferrous metals (e.g. iron and steel)

- Non-ferrous metals (e.g. Cu, Al, Zn, Pb, Ni, among others)

- Inert materials (e.g. glass, ceramics, and concrete, among others)

- Residual fraction (i.e. normally fraction with finest particle size)

Some of these output flows could be used to recover materials through recycling (e.g. glass, inert materials, ferrous and non-ferrous metals) and to produce an alternative fuel (i.e. high calorific value materials), while a certain amount of the residual fraction might need re-landfilling or further processing (Hernández Parrodi et al., 2018b). Comprehensive studies on the resource potential of LFM materials can be found in Wolfsberger et al., 2015, García López et al., 2019, and Hernández Parrodi et al., 2019a.

In general, there are two main strategies to valorize waste in the current waste management system. The first, known as waste-to-material (WtM), targets recycling of waste, such as plastics, metals and minerals, to replace primary raw materials. The second one, known as waste-to-energy (WtE), aims to valorize waste materials with a high calorific value in (co-)incineration plants to produce thermal and electrical energy.

\section{WASTE-TO-MATERIAL}

\subsection{Metals}

Ferrous and non-ferrous metals are considered the most valuable resource extracted from landfills. According to Winterstetter et al., 2015, and Van Vossen \& Prent, 2011, those contribute the most to the revenues from LFM. The technology for recycling and upcycling metal scrap is nowadays the most developed compared to that for other waste fractions, such as inert materials or plastics. For this reason, finding a market for metal scraps coming out from landfilled waste is not considered to be a critical issue. Nevertheless, the quality of the recovered metals from landfilled waste does play a relevant role in the extent of their recyclability and marketability, and, hence, is to be taken into account while assessing the recovery potential and economic feasibility in (E)LFM projects.

A detailed study on the quality assessment of the non-ferrous metals recovered from a Belgian landfill can be found in Lucas et al., 2019.

\subsection{Inert materials}

According to previous investigations, most of the excavated waste in LFM projects corresponds to fine fractions (Hernández Parrodi et al. 2018a). Fine fractions are mostly composed of a mixture of degraded organic matter and weathered inert materials, which, if adequately separated, might be used to produce recycled construction aggregates (e.g. construction sand). The use of inert materials recovered from waste as construction aggregates is regulated by Article 6 of the EU Waste Framework Directive (2008/98/ EC), which states a series of criteria to be complied with in order to recycle such recovered materials. However, additional criteria that depend on local legislation might be enforced as well (EU-Report 26769 EN, 2014).

\subsection{Plastics and other materials}

The recovery of plastic materials from LFM for recycling purposes might be possible; nonetheless, the high degradation state in which these materials are recovered, and their degree of contamination with impurities and surface defilements represent a relevant obstacle to follow the WtM route (Wolfsberger et al., 2015). Therefore, plastics recovered from LFM may result more suitable for the production of RDF, which can be used in WtE co-incineration plants (Bhatnagar et al., 2017).

Other materials, such as organic matter, wood, textile, leather, paper and cardboard cannot be recycled directly to replace primary raw materials due to their level of degradation and contamination, and poor quality (Quaghebeur et al., 2013; Spooren et al., 2013; Wolfsberger et al., 2015) (Table 1).

\section{WASTE-TO-ENERGY}

Carbonaceous material sorted from landfilled waste, which cannot be recycled directly, can be valorized into energy. Three main thermal treatment technologies have been developed in order to recover energy from municipal solid waste (MSW) and industrial waste (IW): incineration, pyrolysis and gasification (Yan et al., 2016; Kalogirou, 2018).

\subsection{Incineration}

Incineration is the most widespread and mature WtE technology to dispose of MSW and IW (the combustible solid waste volume can be reduced up to $90 \%$ ) and, simultaneously, produce electricity and district heating. This process can accept waste without any pre-treatment and in a wide range of compositions and is, therefore, very robust and versatile and relatively simple. Complete combustion 
TABLE 1: Overview of the situation with respect to the utilization of waste-derived aggregates in some selected EU Member States (EU-Report $26769 \mathrm{EN}, 2014)$

\begin{tabular}{|c|c|c|c|c|}
\hline Member State & $\begin{array}{l}\text { Regulation of the use of } \\
\text { waste aggregates? }\end{array}$ & $\begin{array}{l}\text { Criteria on } \\
\text { total content? }\end{array}$ & $\begin{array}{l}\text { Criteria on } \\
\text { leaching? }\end{array}$ & Type(s) of leaching tests required? \\
\hline Austria & Guidelines & Yes & Yes & EN $12457-4(\mathrm{~L} / \mathrm{S}=10 \mathrm{l} / \mathrm{kg})$ \\
\hline Belgium & Yes, in the Flemish region & Yes & Yes & CEN/TS 14405 (L/S=10 I/kg) \\
\hline Czech Republic & Based on Landfill legislation * & Yes & Yes & EN $12457-4(\mathrm{~L} / \mathrm{S}=10 \mathrm{l} / \mathrm{kg})$ \\
\hline Denmark & Yes & Yes & Yes & EN 12457-1 \\
\hline Finland & Yes & Yes & Yes & $\begin{array}{c}\text { CEN/TS 14405; } \\
\text { EN 12457-3 (L/S=10 l/kg) }\end{array}$ \\
\hline France & Yes & Yes & Yes & EN $12457-2$ and 4 ** \\
\hline Germany & $\begin{array}{l}\text { Guidelines (new regulation in } \\
\text { preparation) }\end{array}$ & Yes & Yes & EN 12457-2 and DIN 19528 (new legislation) \\
\hline Hungary & Some & No & Yes & Unknown \\
\hline Italy & Yes & No & Yes & EN $12457-2(\mathrm{~L} / \mathrm{S}=10 \mathrm{l} / \mathrm{kg})$ \\
\hline The Netherlands & Yes & Yes & Yes & CEN/TS 14405 (L/S=10 I/kg) \\
\hline Poland & No & No & No & Unknown \\
\hline Portugal & Some guidelines & No & No & Unknown \\
\hline Slovakia & No & No & No & Unknown \\
\hline Spain & Yes, regional & No & Yes & EN 12457-4 and DIN 38414-S4 \\
\hline Sweden & Guidelines, case by case & Yes & Yes & CEN/TS 14405 (L/S=10 I/kg) \\
\hline
\end{tabular}

* Considering adopting Austrian guidelines

** For compliance testing (CEN/TS 14405 for basic characterization)

of the waste is achieved in a controlled oxidizing environment, usually with excess air, at temperatures that can vary from $800^{\circ} \mathrm{C}$ to $1200^{\circ} \mathrm{C}$, typically in the range $800-900^{\circ} \mathrm{C}$. The carbonaceous solid waste undergoes four consecutive stages: (i) evaporation of the moisture content, (ii) release of volatile hydrocarbons/charcoal formation, (iii) combustion of the volatiles and (iv) combustion of the residual charcoal. The combustion chamber is commonly a moving grate furnace, but also different configurations like fluidized bed and rotary kiln are used. Most of the calorific content of the waste is transferred to flue gases in form of sensible heat and delivered to a downstream power block. Flue gases include products of incomplete combustions (e.g. carbon monoxide, alkenes, organic acids, soot, etc.), particulate matter (usually inorganic salts or oxides mixed with incomplete combustion compounds), acidic gases $\left(\mathrm{HCl}, \mathrm{SO}_{2}, \mathrm{SO}_{3}, \mathrm{NO}_{x^{\prime}}\right.$ etc.), heavy metals and dioxins. Modern flue gas cleaning systems benefit of a wide range of air pollution control techniques that allow to comply with the strictest admissible environmental emissions limits before discharging into the atmosphere. The residues from waste incineration, in the form of bottom ash and air pollution control residues (APCR), are then treated and recycled, e.g. paving roads, or landfilled (Gleis et al., 2001). The overview of a typical incineration plant is shown in Figure 4.

\subsection{Pyrolysis}

Pyrolysis and gasification are sub-processes of incineration, but they can also be entirely distinct technologies. Pyrolysis of carbonaceous solid waste consist of its thermal decomposition, typically in the temperature range 300 $850^{\circ} \mathrm{C}$, in an inert/reducing environment, i.e. with no addition of oxygen. Due to the complex composition of MSW, a multitude of reactions, mainly endothermic, occur simultaneously in the reactor and its output is divided into gaseous products and a solid residue (the so-called char). The first consists mainly of $\mathrm{CO}$ and $\mathrm{H}_{2}$, but includes also $\mathrm{CH}_{4}$ and other volatile organic compounds (VOCs). A fraction of the latter is condensated and results into liquid products: oils, waxes and tars. The solid residue is a mixture of coke and a non-combustible inorganic fraction and, although it can be further processed to release the energy content of the organic part, typically there is low demand for it. The reactor configuration (fixed bed, fluidized bed, screw kiln, rotary drum, etc.) is selected based on the operation mode (batch, semi-continuous or continuous) and on the method used to deliver the heat, usually transferred indirectly, i.e. by thermal conduction. Although pyrolysis allows to reduce the volume of the waste and simultaneously recover energy from it, due to the low energy outputs obtained in the case of MSW, its industrial scale application is very limited.

\subsection{Gasification}

In the gasification process, carbonaceous waste reacts with a gasification agent (oxygen and/or steam) at temperature that vary from 700 to $1600^{\circ} \mathrm{C}$ in partially oxidizing conditions (absence or substoichiometric presence of oxygen) to produce a fuel gas called syngas, which is a mixture of $\mathrm{CO}$ and $\mathrm{H}_{2}$. A significant advantage of gasification is that syngas can be combusted at higher temperatures than those achievable with the original fuel or even in fuel cells, so that the thermodynamic efficiency of the downstream power cycle is enhanced. In addition, problematic chemical elements (e.g. chloride and potassium) can be separated from the syngas, allowing the production of clean combustion flue gases. Furthermore, syngas 


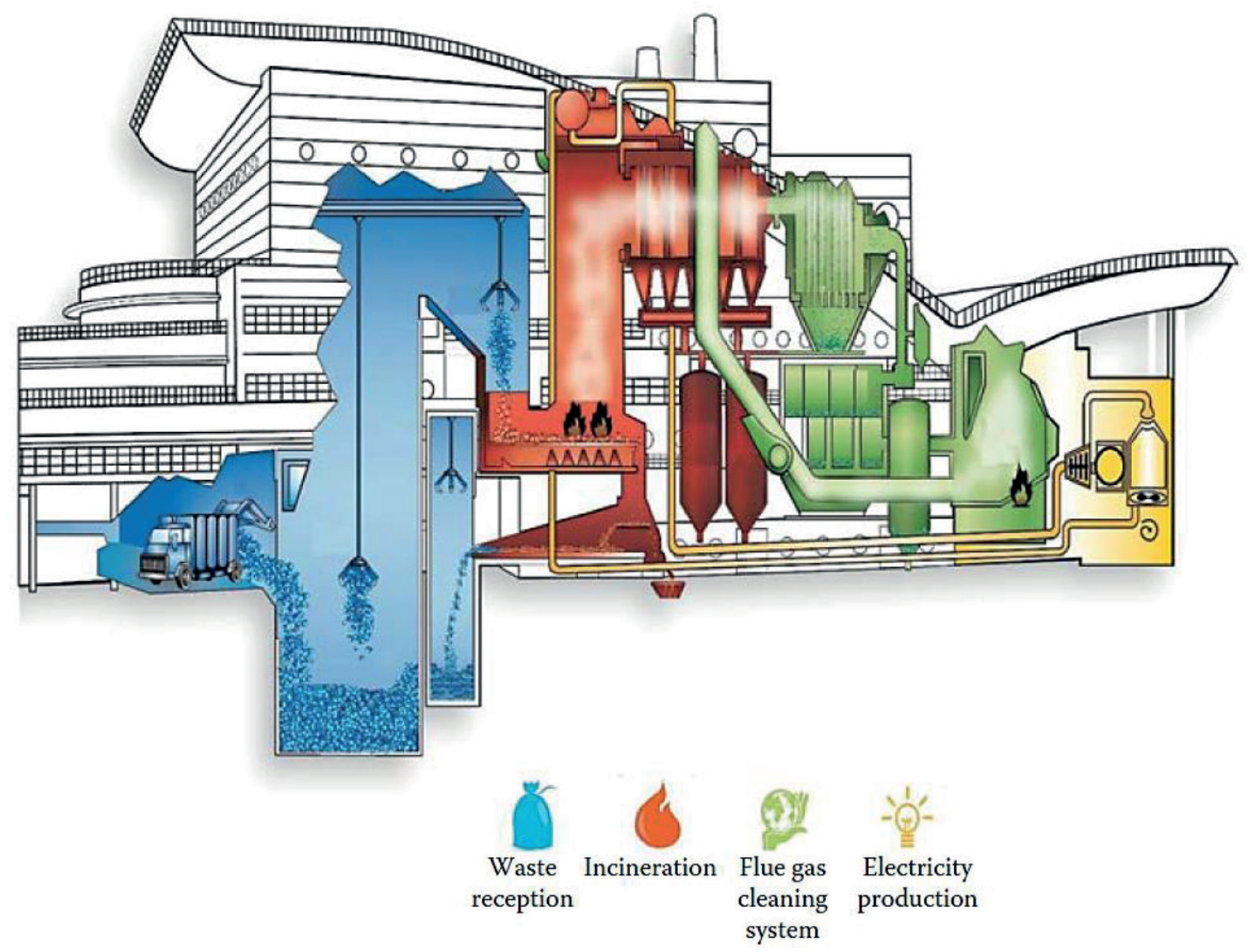

FIGURE 4: Scheme of a MSW incineration plant for power generation (SEVEDE, 2007).

can be stored and used in internal combustion engines or converted into high-purity hydrogen or synthetic fuels. The other products from gasification are a solid inert residue (ash) and tar, which is usually cracked into smaller hydrocarbon molecules in a downstream reactor placed after the gasifier in order to avoid deposit and blockage of the piping. Types of gasifiers include fixed bed, fluidized bed, rotary kiln and other less common configurations. The gasification process consists of several chemical and physical phenomena occurring in series-parallel with each other and, generally, the feedstock is subject to 4 stages (not necessarily carried out in the same reaction chamber): (i) evaporation of the moisture content, (ii) release of volatile hydrocarbons/formation of char (mixture of fixed carbon and inert), (iii) reduction (with steam or hydrogen) of a portion of the fixed carbon with release of hydrocarbons and simultaneous oxidation (with oxygen or steam) of the other fraction of the fixed carbon and some hydrocarbons, (iv) melting of the inorganic residues. The heat released from the exothermic partial oxidation of the waste compensates for the heat absorbed by the endothermic reactions (decomposition and reduction) and for the latent heat of fusion of the inorganic residues. The melting of the ash generates a vitreous inert material that, instead of being landfilled, could be exploited by the construction indust- ry. Considering the potential benefits (e.g. production of a storable and clean energy carrier, significant waste volume reduction and efficient pollution control), gasification has become the most attractive integrated solution for both waste treatment and energy recovery.

\subsection{Other emerging gasification technologies}

In the "autothermal" gasification part of the waste is oxidized instead of being converted into syngas, in order to drive the chemical and physical phenomena that absorb heat. In the "allothermal" gasification the extraction of the energy content of the waste is maximized by preheating it with an auxiliary energy source: external combustion, electrical energy, solar energy, etc. (Fabry et al., 2013; Sanlisoy et al., 2016; Piatkowski et al., 2011a; Loutzenhiser et al., 2017).

\subsubsection{Plasma gasification}

Hot plasma, an ionized gas formed by using electrical energy, can contribute to sustain the high-temperature transformations occurring in the gasification process. The maximum temperature achievable by combustion is around $3000 \mathrm{~K}$ (for the acetylene-oxygen mixture) while plasma can go up to $15000 \mathrm{~K}$. The higher temperature attained allow to break down nearly all compounds into 
their elemental form and significantly accelerate the reaction rates, resulting in a higher waste conversion and cleaner products. Different process configurations are possible depending on where the plasma is injected: in the upper part of the reactor close to the waste inlet, at the bottom close to the molten bath, or in a separate chamber to treat the gases leaving the reactor. The higher the presence of hot plasma, the larger the fraction of the waste which is saved from being oxidized, so that it can be converted into syngas. However, an extensive use of plasma implies a significant electricity consumption that, besides being a potential indirect cause of $\mathrm{CO}_{2}$ emissions, may exceed the energy content of the produced syngas, resulting in a low or even negative net power production of the process.

\subsubsection{Solar gasification}

By concentrating the diluted sunlight over a small area with the aid of mirrors, it is possible to obtain a dense beam of solar radiative energy that can heat up the carbonaceous waste to the high temperatures necessary for its gasification (Steinfeld et al., 2001). The solar energy input saves part of the feedstock from being burned, so that the process has the potential to be free of combustion byproducts and yield a higher syngas output with respect to conventional gasification. Solar gasifiers, which have been demonstrated capable to operate at high temperatures $(>1400 \mathrm{~K})$, can be classified as (i) directly irradiated, where the solid waste is directly exposed to the concentrated radiation, or (ii) indirectly irradiated, where the concentrated solar beam heats up the reactor wall or a heat transfer fluid. Directly irradiated reactors offer efficient heat transfer, but need a transparent window that has to be carefully designed to withstand pressure fluctuations and prevent deposition of particles or condensable compounds on it. Indirectly irradiated reactors eliminate the necessity for a window at the expense of a less efficient heat transfer. The possible reactor configurations can be: packed bed (see
Figure 5a), fluidized bed, entrained flow and vortex flow (see Figure 5b), among others. Solar gasification has the potential to be operated also during off-sun periods (i.e. night-time or cloudy days) with the integration of a thermal energy storage unit that can accumulate high-temperature $\left(>900^{\circ} \mathrm{C}\right)$ solar heat during the day and release it when required (Ströhle et al., 2017; Gigantino et al., 2019).

\subsection{Recycling residues from WtE plants}

Treating MSW, IW or landfill waste in WtE plants does not completely solve the problem of waste disposal. Incineration, pyrolysis and gasification can reduce the volume of waste to a great extent, but there are still solid outputs, which can contain significant amounts of pollutants, such as chlorine, dioxins and heavy metals (Chimenos et al., 1999; Gleis et al., 2001; Sorlini et al, 2017).

Several EU states have adopted a critical attitude toward generation and disposal of waste. It is customary for EU countries, such as Belgium, Finland and the Netherlands to treat and recycle MSW bottom ash from WtE plants as aggregates for construction or road-paving (Kahle et al., 2015; Lynn et al., 2017). However, bottom ash does not always fulfill the requirements in terms of content and leaching of pollutants, so that countries such as Austria and Switzerland are still landfilling the ashes. APCR, such as fly ash or boiler ash, are also some of the outputs from WtE plants, which are considered as hazardous waste and need to be disposed of in special landfills, after metal recovery by the FLUWA process. In this regard, gasification and other novel waste treatment technologies could enable the upcycling of the residues after thermal treatment into a new range of eco-friendly construction materials based on inorganic polymers and glass-ceramics. Novel techniques allow to transform inorganic residue from $\mathrm{WtE}$ plants into thermal and acoustic isolation materials, such as traditional bricks and tiles (Kriskova et al., 2015; Rabelo Monich et al., 2018; Rincon Romero et al., 2018). An example of such upcycled materials is shown in Figure 6.
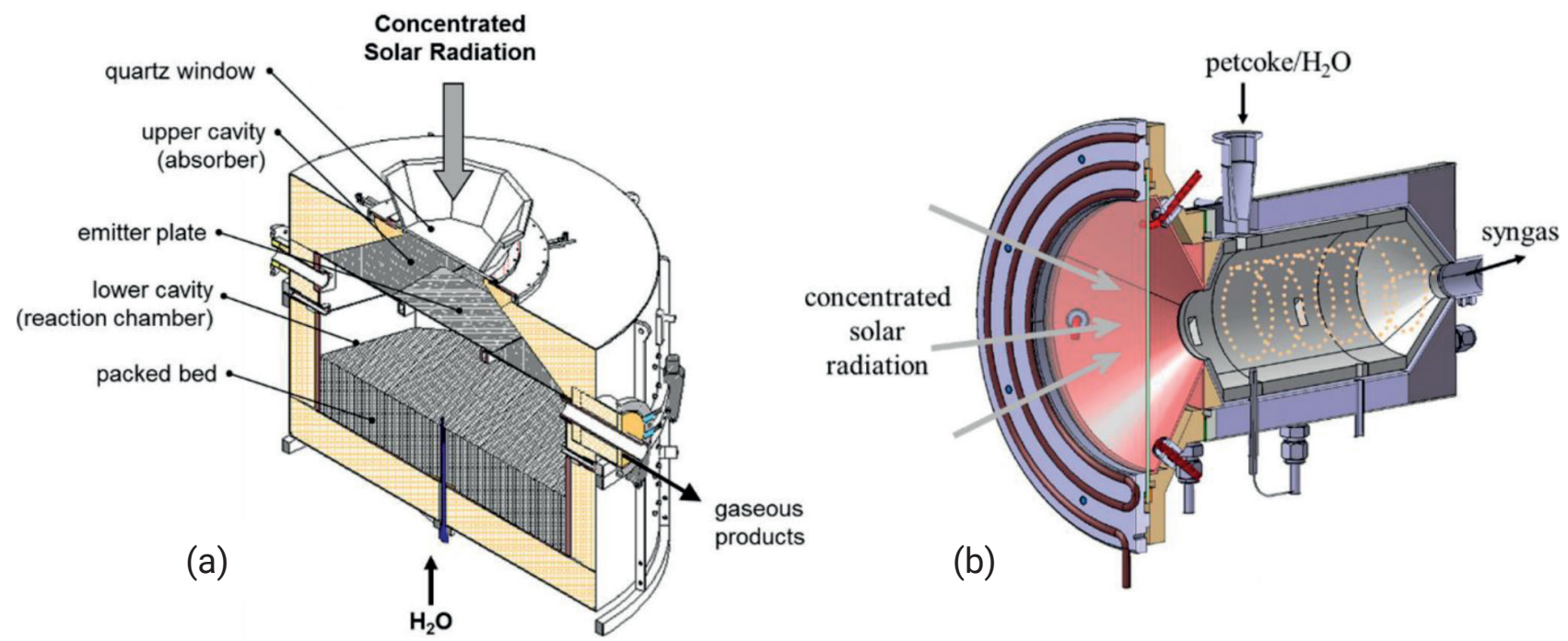

FIGURE 5: Scheme of (a) an indirectly irradiated packed-bed gasifier and of (b) a directly irradiated vortex flow gasifier (Piatkowski et al. 2011b, Z'Graggen et al. 2008). 


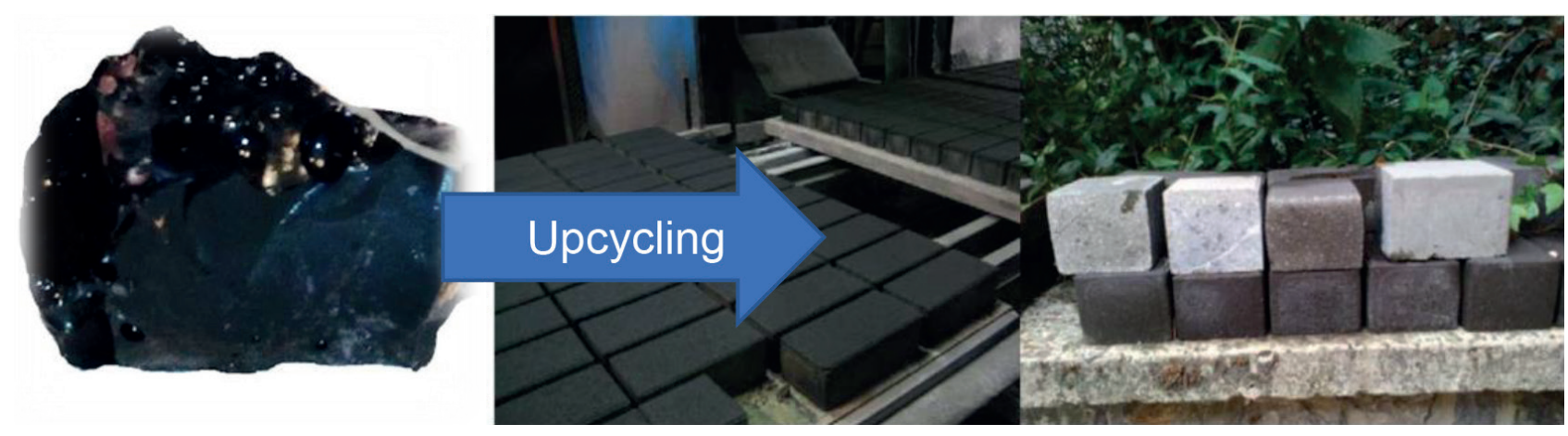

FIGURE 6: Upcycling of vitrified landfill waste into construction materials (Machiels et al., 2017).

However, the final sink of contaminants in this approach is still unclear.

\section{MULTI-CRITERIA ASSESSMENT IN (E)LFM}

During the past decade, multi-criteria assessments (MCAs) of LFM projects have become of growing interest to academia, industry, and policymakers. MCAs of LFM aim to account for impacts and risks from an environmental, economic, and societal perspective. Results of such assessments support LFM stakeholders in the decision-making process among the previously described LFM scenarios, i.e. landfill remediation, classical LFM, and ELFM. As described in the previous parts of this study, these scenarios do not refer to a fixed process chain or technologies, but rather show the evolution of a concept to display the major differences and implications of those scenarios.

Most MCAs of LFM projects address environmental impacts and economic feasibility, while societal impacts are typically not addressed (Krook et al., 2018). Environmental impacts are commonly derived from life cycle and risk assessment (Danthurebandara, 2015; Frändegård et al., 2013a, 2013b; Gusca et al., 2015; Jain et al., 2014; Laner et al., 2016), whereas private economic costs and benefits are often determined by the means of the net present value (NPV) (Frändegård et al., 2015; Hermann et al., 2016b; Kieckhäfer et al., 2017; Laner et al., 2019; Winterstetter et al., 2015). Since societal impacts are of a diverse and often complex nature, including welfare changes as well as health risks, no common assessment method for LFM projects exists (Einhäupl et al. 2019a). Moreover, societal impacts are often strongly related to environmental and economic ones, as health risks are usually a consequence of environmental impacts and taxes are accounted for as a private economic cost, but also represent a societal income. Hence, it is often difficult to define clear boundaries between the different dimensions of sustainability in (E)LFM, especially when considering causal relations between different impacts.

Figure 7 displays the sustainability concept as the basis for a holistic multi-criteria assessment in LFM research. The lack of a common and integrated framework, which considers all three sustainability dimensions, shows the complexity of MCAs for LFM projects. While efforts have been made in literature (Hermann et al., 2016a; Pastre et al., 2018) to assess the feasibility of LFM in a holistic manner, challenges, like emerging technologies or long-term impacts of existing landfills, remain with respect to the estimation of the extent of these environmental, economic and societal factors influencing the feasibility of LFM due to varying contextual conditions and related stakeholder perceptions of drivers and barriers.

\subsection{From landfill mining to enhanced landfill mining: a conceptual and technological evolution of LFM drivers and barriers}

To address the previously mentioned challenges considering future MCA method development and modeling, this study provides a simple synthesis of critical factors that drive or hinder LFM projects as a result of previous sustainability assessments (Table 2). This synthesis discusses motivational drivers and barriers of LFM projects and contrasts the critical factors of the three different LFM scenarios. As previously mentioned, these scenarios represent the evolution of the concept of LFM, which led to changes in perceptions of potential drivers and barriers. For example, while environmental concerns usually drive remediation projects, increasing urbanization and growing resource scarcity have made the reclamation of land and materials important drivers for LFM, still including the potential to reduce surface-, groundwater and soil contamination by excavating the landfill (Marella \& Raga, 2014). In

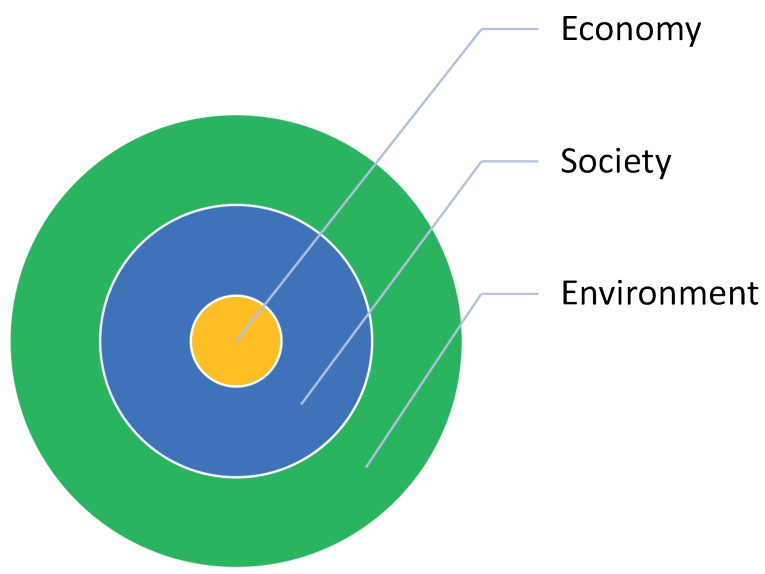

FIGURE 7: The sustainability concept as the basis for multi-criteria assessment in LFM research. 
addition, LFM and ELFM have been linked to the avoidance of potential environmental hazard that is due to flooding risk brought by climate change (Laner et al., 2009a; Wille 2018). This could also contribute to the reduction of aftercare and other pollution-related costs. Moreover, technological development could potentially lead to the further valorization of currently re-landfilled waste streams, or their use in lower value applications, leading to the more integrated approach that characterizes the concept of ELFM. Nevertheless, while the mentioned factors represent important drivers for LFM, the excavation and material valorization processes could also lead to additional costs and impacts on every level of sustainability (Hermann et al., 2016a; Marella et al., 2014; Pastre et al., 2018).

The concept of LFM was first introduced in 1953 in Israel (Calderón Márquez et al., 2019; Krook et al., 2012). The aim of that LFM project was to recover materials as fertilizer, while also recovering ferrous and non-ferrous metals (Calderón Márquez et al., 2019). Since then, around 112 projects worldwide have been studied with objectives ranging from environmental protection, over avoidance of closure and post-closure care, the extension of landfill lifetime, land reclamation, to resource recovery, among others (Calderón Márquez et al., 2019). Drivers for the different landfill mining projects have been exhaustively summarized in the study by Calderón Márquez et al., 2019, and are discussed here in light of the evolution of the LFM concept, with particular focus on European projects.

Environmental protection has indeed been the most important driver in LFM (Calderón Márquez et al., 2019; Danthurebandara, 2015; Gusca et al., 2015; Laner et al., 2016; Marella et al., 2014). The need to reduce soil, surface and groundwater contamination has led to an increased interest in remediation strategies. However, given the high costs of remediation processes, new concepts and technologies were developed with the aim to recover valuable resources from landfills, such as combustibles and metals, to compensate the costs and recover materials (Jones et al., 2013; Krook et al., 2012). The concepts of LFM and ELFM, therefore, developed to further increase the resource recovery potential. As mentioned in Van Passel et al., 2013, apart from technological development (technology push), also regulatory- and market- related factors (regulatory push and market pull) determine the economic, societal and environmental performance of LFM projects. These regulatory push factors include legislative changes due to public and environmental pressures, urban development, subsidy schemes or strategic resource independence, among others. On the other hand, market pull factors include increase in material prices and resource competition or rising land prices that can help to facilitate the excavation and processing of the formally buried waste. Market-related barriers for LFM implementation can include quality standards for secondary raw materials, processing capacities of waste incinerators (Johansson et al., 2017b), for example, or a lack of investments due to awareness gaps among stakeholders (Einhäupl et al., 2018). Regulatory barriers mostly derive from legal uncertainty, since it is often unclear if gate fees or taxes that could hinder a project's implementation have to be paid or not (Johans- son et al., 2017a). Moreover, public opposition due to environmental uncertainties and the risk of disamenities, i.e. dust, odor, noise, and traffic, can also hinder LFM projects.

During the past years and throughout the studies worldwide, drivers for the mentioned LFM projects have since varied, based on time or local and regional requirements for land-use and landfill void space. Moreover, new landfill regulations, such as the Landfill Directive 1999/EC/31 and similar global regulations on waste disposal, increased the interest in LFM projects to reduce risks of contamination and the related costs, as well as to comply with closure and post-closure requirements (Calderón Márquez et al., 2019; Laner et al., 2016). Today, landfills predating the 1999 Landfill Directive are commonly referred to as "dumpsites". As most dumpsites are lacking up-to-date environmental protection measures, classic remediation has usually motivated the excavation of such landfills.

While regulation can push project implementation, as well as hinder it, it is important to take a closer look at the regulatory situation of (E)LFM today. In general, the socalled EU Landfill Directive defines the legal framework for the design, management and closure of landfills (Council Directive, 1999). The so-called EU Waste Directive defines the regulations for waste treatment and safety issues when treating hazardous waste materials, for example (Council Directive, 2008). Since the request for an ELFM amendment to the Landfill Directive was rejected by the EU Commission in 2018, no specific regulations for (E)LFM exist (Jones et al., 2018), adding to the legal uncertainty. However, according to the EU Commission and a legal report from Austria, no current regulations prohibit (E)LFM operations, even at an industrial scale and scope (Eisenberger, 2015; Jones et al., 2018). Nonetheless, the lack of overarching European legislation leaves member states with a variety of options to deal with (E)LFM and gives little room to address common challenges for its implementation (Einhäupl et a., 2019b).

Table 2 summarizes the drivers for LFM projects and their evolution from the remediation concepts to enhanced landfill mining. As shown in Table 2, the goal of ELFM compared to LFM is to maximize the recovery of resources while complying with all other objectives (environmental protection, societal benefits, etc.). Hence, to minimize the re-disposal of excavated fractions is an important focus of ELFM projects.

\subsection{Critical factors of LFM projects}

Increasing environmental and societal pressures and higher resource recovery targets have led to increasing challenges related to the waste processing technologies and, therefore, to the quality and quantity of the materials and energy recuperation. Economic, environmental and societal assessments of LFM and ELFM projects have highlighted the influence of critical factors in the feasibility and potential benefits of such projects. For example, while potential economic benefits could mainly derive from land reclamation, and material and energy valorization (Hermann et al., 2016b; Krook \& Baas, 2013), potential costs are related to the excavation and processing of the different waste fractions (Hermann et al., 2016b). These costs 
TABLE 2: Drivers and barriers throughout the evolution of the LFM concepts.

\begin{tabular}{|c|c|c|c|}
\hline & Landfill remediation & Landfill mining & Criteria on leaching? \\
\hline Drivers & $\begin{array}{l}\text { Environmental protection } \\
\text { (remediation) }\end{array}$ & $\begin{array}{l}\text { - Environmental protection (remediation) and } \\
\text { - } \text { risk mitigation } \\
\text { - Legislative changes } \\
\text { - Extension of useful landfill lifetime } \\
\text { - Mitigation of closure and post-closure after- } \\
\text { care } \\
\text { - Urban development } \\
\text { - Flooding risk }\end{array}$ & $\begin{array}{l}\text { LFM drivers with the addition of: } \\
\text { - Resource recovery (maximization) } \\
\text { - Innovative landfill management concept: } \\
\text { integrated valorization routes } \\
\text { - Minimization of re-landfilling of waste } \\
\text { - Resource independence } \\
\text { - Increasing resource scarcity }\end{array}$ \\
\hline Barriers & - Remediation costs & $\begin{array}{l}\text { Low market prices for primary and secondary } \\
\text { raw materials } \\
\text { - Relatively high processing costs }\end{array}$ & $\begin{array}{l}\text { - Public opposition } \\
\text { - Quality standards } \\
\text { - Legal uncertainty } \\
\text { - Taxes and fees } \\
\text { - Technological challenges }\end{array}$ \\
\hline
\end{tabular}

are highly dependent on the waste composition and quality, as well as technology choices. Implied environmental impacts again can cause potential societal impacts that can lead to public opposition, for example.

In general, technology availabilities and efficiencies for processing landfilled waste are still uncertain and under current investigation. These technological uncertainties make it difficult to assess LFM projects, as potentially related costs, risks and impacts could outweigh the potential benefits (Hermann et al., 2016b; Krook et al., 2012).

In the relevant literature, critical factors are often discussed based on their influence on the economic, environmental or societal performance of the LFM projects (Danthurebandara, 2015; Frändegård et al., 2013b; Gusca et al., 2015; Hermann et al., 2014; Laner et al., 2016). However, most factors have implications for two or all sustainability dimensions. For example, environmental protection, which addresses the need to minimize soil, surface and groundwater contamination, has mostly been discussed as an environmental driver. Nonetheless, this has economic and societal implications in the reduction of pollution-related costs or of health risks to local communities. The recovery of materials and their marketability has potential environmental and economic benefits from the avoided production of primary materials, and the revenues from the secondary raw materials. From a societal perspective processing and recycling of waste could lead to job creation, avoid post-closure costs and risks, or increase property values. Given the interconnection of the factors between the three sustainability dimensions, a few studies have divided the critical factors affecting the performance and feasibility of LFM projects according to the level of influence (Laner et al., 2016; Winterstetter, 2018; Winterstetter et al., 2018). In particular, site-, project-, and system-level factors have been identified, which are summarized in Table 3.

At a site-level, waste composition is one of the main critical factors in LFM projects and multi-criteria assessments, and strictly related to the specific landfill. Waste composition influences the emission potential of the landfill and, therefore, the environmental impacts, pollution related costs and remediation requirements. It also greatly affects the resource recovery potential of LFM and the valorization routes suitable for the specific case (García López et al., 2019; Hernández Parrodi et al., 2018b; Quaghebeur et al., 2013). Moreover, disamenities like dust and odor are partly dependent on the waste composition. Quality and quantity of materials define the choice of technologies and their efficiencies, which have proven to be critical factors in previous economic and environmental studies of LFM (Danthurebandara, 2015; Frändegård et al., 2013a; Gusca et al., 2015; Laner et al., 2016). In environmental and economic assessments, given the importance of environmental protection as one of the main drivers, the reference case is also of great importance. It represents the importance of leaving the landfill as it is, with environmental, societal and economic consequences. These are related to the landfill emission potential which can last for centuries after landfill closure (Doka et al., 2005; Laner et al., 2009b), and which are respectively related to the waste composition and its degradability, as well as landfill design and management (Laner, 2011a).

At a project-level, technology choices and their efficiencies greatly affect the performance of LFM. In particular, technology choices for WtM and WtE, combined with the background energy system and the waste quality, could be decisive in potential applications of LFM (Frändegård et al., 2013a; Gusca et al., 2015; Laner et al., 2016). In fact, the overall aim is to outweigh the costs and impacts related to the reference case with the processing and recovery of resources. Excavation, separation and sorting technologies could have high environmental and economic impacts, also in relation to the quantity and quality of the materials recovered. On-site and off-site processing options also affect the performance, as transportation distances have been identified as critical factors (Frändegård et al., 2013a; Gusca et al., 2015). Given the high amounts of waste that LFM projects could address, logistics also becomes an important factor. Storage and processing capacities and equipment are also crucial for the design of valorization routes, the quality and quantity of recoverable materials (Kieckhäfer et al., 2017). In addition, the choice of project motivation, i.e. the main driver, in terms of land recovery or void space recovery has critical influence on the performance of an LFM project. Land recovery means external re-landfilling of fine fractions, while void space recovery means internal re-landfilling. With the large share of fine fractions in the landfill waste composition (Hernández Parrodi et al., 2018a), its subsequent choice of management is particularly important (Laner et al., 2019).

System-level factors are those which cannot be ad- 
TABLE 3: Selection of critical factors for (E)LFM implementation at the level of impact.

\begin{tabular}{|c|c|c|}
\hline \multicolumn{3}{|c|}{ Critical factors } \\
\hline Site-specific & Project-level & System-level \\
\hline $\begin{array}{l}\text { Waste composition: quantity and quality of re- } \\
\text { sources for recovery } \\
\text { - Reference case }\end{array}$ & $\begin{array}{l}\text { Technology choices and efficiencies: } \\
\text { - Excavation, separation, and sorting (mobile, } \\
\text { stationary and advanced, etc.) } \\
\text { - WtE treatment: type and efficiency, energy } \\
\text { carriers } \\
\text { - Quality of the materials recovered and mar- } \\
\text { ketability } \\
\text { - Logistics } \\
\text { - Energy and processing costs } \\
\text { - Investment and operating costs, costs for } \\
\text { external treatment and disposal } \\
\text { - Land or void space recovery } \\
\text { - Avoided impacts }\end{array}$ & $\begin{array}{l}\text { - Background energy system } \\
\text { - Primary material production system } \\
\text { - Transportation: requirements and distances } \\
\text { - Financial effects } \\
\text { - Materials and energy prices } \\
\text { - Legal, institutional, organizational, and societal } \\
\text { structures: } \\
\text { - Policy support } \\
\text { - Community engagement }\end{array}$ \\
\hline
\end{tabular}

dressed for each case specifically, but that influence the environmental, economic and societal performances as they refer to country-specific, European-, or even global structures. These include legal, institutional, organizational and societal structures. In particular, the background energy system influences the environmental impacts based on the energy production mix of the country of implementation of the project. Materials and energy prices, and their variation in time affect the revenues of materials and energy recovery, also in relation to primary raw materials. The marketability of valorized WtE residues is also uncertain, as different studies have assumed different prices to no market at all (Danthurebandara et al., 2015; Winterstetter et al., 2015). Similarly, the value of recovered land and landfill void space depends on the existing market conditions, but also influenced by site-specific factors like location: whether a landfill is situated nearby a residential, industrial or natural areas (Marella et al., 2014; Van Passel et al., 2013).

Societal aspects are therefore becoming of increasing interest in the multi-criteria assessment of LFM, and have been mentioned throughout the relevant literature. When assessed, however, commonly interviews and ranking systems are used (Hermann et al., 2016b; Pastre et al., 2018) as well as monetization techniques (Marella et al., 2014; Winterstetter et al., 2018). Consequently, considerable subjectivity resonates with the assessment of societal factors, and various societal effects become entangled. This again leaves decision-makers having to deal with major uncertainties when evaluating societal risks and benefits, such as safety issues, health implications through groundwater contamination (Krook et al., 2012), disamenities (Einhäupl et al., 2018), welfare changes (Damigos et al., 2016) and so on. Before evaluating these risks and benefits it is important to carefully analyze societal drivers and barriers for LFM implementation to better understand the origins and mechanisms behind the impacts.

When integrating economic, environmental and societal impacts and perspectives into LFM multi-criteria assessment, several issues have to be addressed. LFM multi-criteria assessment has to deal with intra- and interdimensional trade-offs and conflicts. For example, taxes for re-landfilling excavated waste is a private economic cost and could, thus, hinder a project's implementation. On the other hand, these tax revenues are also a societal benefit. Moreover, different stakeholders are affected by various societal and environmental impacts. Emissions like particular matter coming from LFM operations affect neighboring communities, for example, while avoided impacts are often manifested in other locations or at a global level. To deal with these issues more research is needed. Specifically, the most important influencing factors on societal risks and benefits have to be identified and their interaction with private economic and environmental aspects analyzed.

\section{CONCLUSIONS}

This review article has extensively highlighted the current scenarios for landfill management and potential scenarios for the combined valorisation of waste, as both materials (WtM) and energy (WtE).

Landfills represent a source of hazards to human health and the environment. Moreover, the long-term potential emissions of landfills and the risk of failure of the containment systems, increase the need for aftercare activities and their related costs. In a context of lack of land surface and primary resources, landfills also represent a source of feedstock that could be recovered to answer the increasing demand for raw materials. LFM aims at addressing the potential to recover waste from landfills, while reducing the long-term impacts of landfills by remediating the sites.

Different scenarios can be considered which address LFM to different extents. Overall, the choice of scenario depends on technical, as well as economic, environmental and societal aspects. New technologies are under research to increase the recovery potential of waste materials, such as MSW and excavated waste from landfills. One of the main factors that influences the technical feasibility and efficiency of the recovery processes, is the quality of landfilled waste, since its heterogeneity, agglomeration, degradation and contamination could hinder the potential for material and energy recovery. Therefore, material composition and physicochemical properties of the waste disposed of in a landfill site are some of the preliminary and most important information to be gathered in order to assess the economic, technical and environmental feasibility of the project. Geophysical methods could be used to determine the subsurface structures and landfilled waste characteristics in a rough manner without the need of an invasive 
exploration, as well as to identify the most interesting area, in terms of depth, water content and presence of certain materials, before carrying out the extraction of landfilled waste. This could greatly reduce the exploration costs and be useful to develop a procedure to either discard or select the most appropriate sites for (E)LFM.

The recovery of material and energy from landfilled waste can be achieved through the implementation of relatively simple separation methods, such as particle size classification, ferrous and non-ferrous metal separation, density classification and sensor-based sorting, coupled with thermochemical valorization technologies and residues upcycling techniques. Gasification, among other novel waste treatment technologies, could enable the upcycling of the residues after thermal treatment into a new range of eco-friendly construction materials based on inorganic polymers and glass-ceramics, which allow to transform inorganic residue from WtE plants into thermal and acoustic isolation materials, such as traditional bricks and tiles.

As for the technical aspects, the multi-criteria assessment of ELFM is also influenced by the same waste- and technology related factors. These, together with site-specific conditions, market and regulatory aspects, influence the environmental, economic and societal impacts of this kind of projects. Intra- and interdimensional conflicts should be identified and taken into account for a broader assessment. The most influencing factors need to be considered at different levels to cover landfill emissions and societal impacts (site-level), include technology choices (project-level) and take into account the regulatory context (system-level) and background system.

\section{ACKNOWLEDGMENTS}

This research has been funded by the European Union's Horizon 2020 research and innovation programme under the Marie Skłodowska-Curie grant agreement No. 721185 "NEW-MINE" (EU Training Network for Resource Recovery through Enhanced Landfill Mining; www.new-mine.eu).

\section{REFERENCES}

Bhatnagar, A., Kaczala, F., Burlakovs, J., Kriipsalu, M., Hogland, M., \& Hogland, W. (2017). Hunting for valuables from landfills and assessing their market opportunities A case study with Kudjape landfill in Estonia. Waste Management \& Research, 35(6), 627-635. https://doi.org/10.1177/0734242X17697816

Bobe, C., Van De Vijver, E., \& Van Meirvenne, M. (2018). Exploring the potential of electromagnetic surface measurements for the characterization of industrial landfills. Proceedings of the 4th International Symposium on Enhanced Landfill Mining, 45-50. Mechelen, Belgium.

Brunner, P. (2004). Material Flow Analysis and the Ultimate Sink. Journal of Industrial Ecology, 8(3), 4-7. https://doi. org/10.1162/1088198042442333

Cha, M. C., Yoon, B. H., Sung, S. Y., Yoon, S. P., \& Ra, I. W. (1997). Mining and remediation works at Ulsan landfill site. Proceedings Sardinia '97, 553-558. Sardinia, Italy.

Chian, E. S. K., \& DeWalle, F. B. (1976). Sanitary landfill leachates and their treatment. ASCE J Environ Eng Div, 2(2), 411-431.

Chimenos, J. M., Segarra, M., Fernández, M. A., \& Espiell, F. (1999). Characterization of the bottom ash in municipal solid waste incinerator. Journal of Hazardous Materials, 64(3), 211-222. https:// doi.org/10.1016/S0304-3894(98)00246-5
Cossu, R., Hogland, W., \& Salerni, E. (1996). Landfill mining in Europe and USA. ISWA Yearbook, 107-114.

Council Directive. (1999). Council Directive 1999/31/EC on the landfill. Official Journal of the European Communities, (10), L182/1-19. https://doi.org/10.1039/ap9842100196

Council Directive. Council directive 2008/98/EC on waste framework Official Journal of the European Communities $\S(2008)$.

Damigos, D., Menegaki, M., \& Kaliampakos, D. (2015). Monetizing the social benefits of landfill mining: Evidence from a Contingent Valuation survey in a rural area in Greece. Waste Management, 51, 119-129. https://doi.org/10.1016/j.wasman.2015.12.012

Danthurebandara, M., Van Passel, S., Vanderreydt, I., \& Van Acker, K., (2015). Environmental and economic performance of plasma gasification in enhanced landfill mining. Waste Management, 45, 458467. https://doi.org/10.1016/j.wasman.2015.06.022

Dickinson, W. (1995). Landfill mining comes of age. Solid Waste Technologies, 9, 42-47.

Doka, G., Life, D., \& Assessments, C. (2005). Assessing Long-term Effects of Municipal Solid Waste. Proceedings of the 1st BOKU Waste Conference, 'Waste Management in the Focus of Controversial Interests' , 4 - 6 April 2005, Vienna, Austria.

Einhäupl, P., Krook, J., Svensson, N., Van Acker, K., \& Van Passel, S. (2018). Enhanced Landfill Mining at the Remo Site: Assessing Stakeholders' perspectives for Implementation. In P. T. Jones \& L. Machiels (Eds.), Proceedings of the 4th International Symposium on Enhanced Landfill Mining, 367-377. Mechelen, Belgium.

Einhäupl, P., Krook, J., Svensson, N., Van Acker, K., \& Van Passel, S. (2019a). Eliciting stakeholder needs - An anticipatory approach assessing enhanced landfill mining. Waste Management, 98, 113-125. https://linkinghub.elsevier.com/retrieve/pii/ S0956053X19305203

Einhäupl, P., Van Acker, K., \& Van Passel, S. (2019b). Integrating Societal Impacts into Enhanced Landfill Mining Assessment. 17th International Waste Management and Landfill Symposium. September 30 - October 4, Santa Margherita di Pula, Italy.

Eisenberger, M. (2015). Gutachten über sich ergebende Rechtsfragen zum Projekt LAMIS-Landfill Mining Österreich-Pilotregion Steiermark. Graz.

Fabry, F., Rehmet, C., Rohani, V., \& Fulcheri, L. (2013). Waste gasification by thermal plasma: a review. Waste and Biomass Valorization, 4(3), 421-439. https://doi.org/10.1007/s12649-013-9201-7

Frändegård, P., Krook, J., Svensson, N., \& Eklund, M. (2013). A novel approach for environmental evaluation of landfill mining. Journal of Cleaner Production, (55), 24-34. https://doi.org/10.1016/j.jclepro.2012.05.045

García López, C., Ni, A., Hernández Parrodi, J.C., Küppers, B., Raulf, K. \& Pretz, T. (2019). Characterization of landfill mining material after ballistic separation to evaluate material and energy recovery potential. Detritus, 8(1), 5-23. https://doi.org/10.31025/26114135/2019.13780.

Gigantino, M., Kiwic, D., \& Steinfeld, A. (2019). Thermochemical energy storage via isothermal carbonation-calcination cycles of MgO-stabilized $\mathrm{SrO}$ in the range of $1000-1100^{\circ} \mathrm{C}$. Solar Energy, 188, 720729.

Gleis, J., Gamer, J., Mützenich, S., Mischer, B., Schimer, B., \& Neukirchen, J. (2001). BREF-“Waste Incineration Plants". Germany.

Gusca, J., Fainzilbergs, M., \& Muizniece, I. (2015). Life Cycle Assessment of Landfill Mining Project. Energy Procedia. https://doi. org/10.1016/j.egypro.2015.06.047

Hellweg, S., \& Frischknecht, R. (2004). Evaluation of Long-Term Impacts in LCA. The International Journal of Life Cycle Assessment, 9(5), 339-341. https://doi.org/10.1007/BF02979427

Hellweg, S., Hofstetter, B., \& Hungerbiihler, K. (2003). Case Study Discounting and the Environment Should Current Impacts be Weighted Differently than Impacts Harming Future Generations? 8(1), 8-18.

Hermann, R., Baumgartner, R. J., Vorbach, S., Wolfsberger, T., Ragossnig, A., \& Pomberger, R. (2016). Holistic assessment of a landfill mining pilot project in Austria: Methodology and application. Waste Management \& Research. https://doi. org/10.1177/0734242X16644517

Hermann, Robert, Wolfsberger, T., Pomberger, R., \& Sarc, R. (2016) Landfill mining: Developing a comprehensive assessment method. https://doi.org/10.1177/0734242X16657610

Hernández Parrodi, J.C., Höllen, D., \& Pomberger, R. (2018a). Characterization of fine fractions from landfill mining: A review of previous investigations. Detritus, 2(1), 46-62. https://doi.org/10.31025/2611$4135 / 2018.13663$ 
Hernández Parrodi, J.C., Höllen, D., \& Pomberger, R. (2018b). Potential and main technological challenges for material and energy recovery from fine fractions of landfill mining: A critical review. Detritus, 3(1), 19-29. https://doi.org/10.31025/2611-4135/2018.13689

Hernández Parrodi, J.C., García López, C., Küppers, B., Raulf, K., Vollprecht, D., Pretz, T., \& Pomberger, R. (2019a). Case study on enhanced landfill mining at Mont-Saint-Guibert landfill in Belgium: Characterization and potential of fine fractions. Detritus, 8(1), 47-61. https:// doi.org/10.31025/2611-4135/2019.13877

Hernández Parrodi, J.C., Raulf, K., Vollprecht, D., Pretz, T., \& Pomberger, R. (2019b). Case study on enhanced landfill mining at Mont-SaintGuibert landfill in Belgium: Mechanical processing of fine fractions for material and energy recovery. Detritus, 8(1), 62-78. https://doi. org/10.31025/2611-4135/2019.13878

Hogland, W. (2002). Remediation of an Old Landfill Site. 1(1), 49-54.

Höxter, H. G. (2001). Appropriate Design and Operation of Sanitary Landfills. Tashkent, Uzbekistan.

Johansson, N., Krook, J., \& Eklund, M. (2017a). The institutional capacity for a resource transition-A critical review of Swedish governmental commissions on landfill mining. Environmental Science \& Policy, 70, 46-53. https://doi.org/10.1016/j.envsci.2017.01.005

Johansson, N., Krook, J., \& Frändegård, P. (2017b). A new dawn for buried garbage? An investigation of the marketability of previously disposed shredder waste. Waste Management, 60, 417-427. https://doi.org/10.1016/j.wasman.2016.05.015

Jones, P. T., Geysen, D., Rossy, A., \& Bienge, K. (2010). Enhanced Landfill Mining (ELFM) and Enhanced Waste Management (EWM) Essential components for the transition to Sustainable Materials Management (SMM). First International Academic Symposium on Enhanced Landfill Mining. Houthalen-Helchteren, Belgium.

Jones, P. T., Geysen, D., Tielemans, Y., Van Passel, S., Pontikes, Y., Blanpain, B., ... Hoekstra, N. (2013). Enhanced Landfill Mining in view of multiple resource recovery: a critical review. Journal of Cleaner Production, 55, 45-55. https://doi.org/10.1016/j.jclepro.2012.05.021

Jones, P. T., Wille, J. E., \& Krook, J. (2018). 2nd ELFM Seminar in the European Parliament: 5 Lessons Learned Why we need to develop a broad Dynamic Landfill Management strategy and vision for Europe's 500,000 landfills. Policy Brief, EU Training Network for Resource Recovery through Enhanced Landfill. (December 2018), $1-12$.

Kahle, K., Kamuk, B., Kallesøe, J., Fleck, E., Lamers, F., Jacobsson, L., ... Hannemanns. (2015). Bottom Ash from Wte Plants Metal Recovery and Utilization. $1-30$

Kalogirou, E. N. (2017). Waste-to-Energy technologies and global applications. CRC Press.

Kriskova, L., Machiels, L., \& Pontikes, Y. (2015). Inorganic Polymers from a Plasma Convertor Slag: Effect of Activating Solution on Microstructure and Properties. Journal of Sustainable Metallurgy, 1(3), 240-251. https://doi.org/10.1007/s40831-015-0022-8

Krogmann, U., \& Qu, M. (1997). Landfill mining in the United States. Proceedings Sardinia '97, 543-552. Cagliari, Italy.

Krook, J., Svensson, N., \& Eklund, M. (2012). Landfill mining : A critical review of two decades of research. 32, 513-520. https://doi. org/10.1016/j.wasman.2011.10.015

Krook, J., \& Baas, L. (2013). Getting serious about mining the technosphere: A review of recent landfill mining and urban mining research. Journal of Cleaner Production, 55, 1-9. https://doi. org/10.1016/j.jclepro.2013.04.043

Krook, J., Svensson, N., Van Acker, K., \& Van Passel, S. (2018). How to Evaluate (Enhanced) Landfill Mining: A Critical Review of REcent Environmental and Economic Assessments. In P. T. Jones \& L. Machiels (Eds.), 4th International Symposium on Enhanced Landfill Mining, 317-332. Mechelen, Belgium

Küppers, B., Hernández Parrodi, J.C., García López, C., Pomberger R., \& Vollprecht, D. (2019). Potential of sensor-based sorting in enhanced landfill mining. Detritus, 8(1), 24-30. https://doi. org/10.31025/2611-4135/2019.13875

Laner, D., Fellner, J., Brunner, \& P.H. (2009a). Flooding of municipal solid waste landfills - An environmental hazard? Science of the Total Environment, 407, 3674-3680. https://doi.org/10.1016/j.scitotenv.2009.03.006

Laner, D. (2009b). The consideration of long-term emissions from landfills within life-cycle assessment. Waste Management \& Research, 463-470. https://doi.org/10.1177/0734242X09102335
Laner, D. (2011a). Understanding and evaluating long-term environmental risks from landfills [online]. 1-225

Laner, D., Fellner, J., \& Brunner, P. H. (2011b). Environmental compatibility of closed landfills - assessing future pollution hazards. Waste Management \& Research : The Journal of the International Solid Wastes and Public Cleansing Association, ISWA, 29(1), 89-98. https://doi.org/10.1177/0734242X10387655

Laner, D., Fellner, J., \& Brunner, P. H. (2012). Site-specific criteria for the completion of landfill aftercare. Waste Management \& Research: The Journal of the International Solid Wastes and Public Cleansing Association, ISWA, 30(9 Suppl), 88-99. https://doi. org/10.1177/0734242X12453610

Laner, D., Cencic, O., Svensson, N., \& Krook, J. (2016). Quantitative analysis of critical factors for the climate impact of landfill mining. Environmental Science \& Technology. https://doi.org/10.1021/acs. est. $6 \mathrm{~b} 01275$

Laner, D., Esguerra, J. L., Krook, J., Horttanainen, M., Kriipsalu, M. Rosendal, R. M., \& Stanisavljević, N. (2019). Systematic assessment of critical factors for the economic performance of landfill mining in Europe: What drives the economy of landfill mining? Waste Management, 95, 674-686. https://doi.org/10.1016/j.wasman.2019.07.007

Loutzenhiser, P. G., \& Muroyama, A. P. (2017). A review of the state-ofthe-art in solar-driven gasification processes with carbonaceous materials. Solar Energy, 156, 93-100. https://doi.org/10.1016/j. solener.2017.05.008

Lucas, H., García López, C., Hernández Parrodi, J.C., Vollprecht, D., Raulf, K., Pomberger, R., et al. (2019). Quality assessment of non-ferrous metals in landfill mining: A case study in Belgium. Detritus, (8)1, 79-90. https://doi.org/10.31025/2611-4135/2019.13879

Lynn, C. J., Ghataora, G. S., \& Dhir OBE, R. K. (2017). Municipal incinerated bottom ash (MIBA) characteristics and potential for use in road pavements. International Journal of Pavement Research and Technology, 10(2), 185-201. https://doi.org/10.1016/j. ijprt.2016.12.003

Machiels, L., Arnout, L., Yan, P., Jones, P. T., Blanpain, B., \& Pontikes, Y. (2017). Transforming Enhanced Landfill Mining Derived Gasification/Vitrification Glass into Low-Carbon Inorganic Polymer Binders and Building Products. Journal of Sustainable Metallurgy, 3(2), 405-415. https://doi.org/10.1007/s40831-016-0105-1

Marella, G., \& Raga, R. (2014). Use of the Contingent Valuation Method in the assessment of a landfill mining project. Waste Management. https://doi.org/10.1016/j.wasman.2014.03.018

Meegoda, JN., Hettiarachchi, H., \& Hettiaratchi, P. (2016). Landfill Design and Operation. In J. W. C. Wong, R. Y. Surampalli, T. C. Zhang, R. D. Tyagi, \& A. Selvam (Eds.), Sustainable Solid Waste Management: Vol. Chapter 18. Reston, VA: American Society of Civil Engineers.

Obersteiner, G., Binner, E., Mostbauer, P., \& Salhofer, S. (2007). Landfill modelling in LCA - A contribution based on empirical data. Waste Management, 27, 58-S74. https://doi.org/10.1016/j.wasman.2007.02.018

Pastre, G., Griffiths, Z., Val, J., Tasiu, A. M., Camacho-Dominguez, E. V., Wagland, S., \& Coulon, F. (2018). A Decision Support Tool for Enhanced Landfill Mining. Detritus, 01(1), 91-101. https://doi. org/10.26403/detritus/2018.5

Piatkowski, N., Wieckert, C., Weimer, A. W., \& Steinfeld, A. (2011a). Solar-driven gasification of carbonaceous feedstock-a review. Energy \& Environmental Science, 4(1), 73-82. https://doi.org/10.1039/ c0ee00312c

Piatkowski, N., \& Steinfeld, A. (2011b). Solar gasification of carbonaceous waste feedstocks in a packed-bed reactor-Dynamic modelling and experimental validation. AIChE journal, 57(12), 3522-3533. https://doi.org/10.1002/aic.12545

Pivato, A. (2011). Landfill Liner Failure: An Open Question for Landfill Risk Analysis. 2011(May), 287-297. https://doi.org/10.4236/ jep.2011.23032

Quaghebeur, M., Laenen, B., Geysen, D., Nielsen, P., Pontikes, Y., Van Gerven, T., \& Spooren, J. (2013). Characterization of landfilled materials: Screening of the enhanced landfill mining potential. Journal of Cleaner Production, 55, 72-83. https://doi.org/10.1016/j. jclepro.2012.06.012 
Rabelo Monich, P., Rincon, A., Daniel, H., \& Bernardo, E. (2018). Porous glass-ceramics from alkali activation and sinter-crystallization of mixtures of waste glass and residues from plasma processing of municipal solid waste. 188, 871-878. https://doi.org/10.1016/j. jclepro.2018.03.167

Rincon Romero, A., Salvo, M., \& Bernardo, E. (2018). Up-cycling of vitrified bottom ash from MSWI into glass-ceramic foams by means of 'inorganic gel casting' and sinter-crystallization. Construction and Building Materials, 192, 133-140. https://doi.org/10.1016/j. conbuildmat.2018.10.135

Sanlisoy, A., \& Carpinlioglu, M. O. (2017). A review on plasma gasification for solid waste disposal. International Journal of Hydrogen Energy, 42(2), 1361-1365. http://dx.doi.org/10.1016/j.ijhydene.2016.06.008

SEVEDE (2007). Annual Report 2007, Paris, France.

Sorlini, S., Collivignarelli, M. C., \& Abbà, A. (2017). Leaching behaviour of municipal solid waste incineration bottom ash: From granular material to monolithic concrete. Waste Management \& Research, 35(9), 978-990. https://doi.org/10.1177/0734242X17721340

Spencer, R. (1990). Landfill space reuse. Biocycle, 31, 30-33.

Spooren, J., Quaghebeur, M., Nielsen, P., Blanpain, B., \& Pontikes, Y. (2013). Material recovery and upcycling within the ELFM concept of the Remo case. 2nd International Academic Symposium on Enhanced Landfill Mining.

Steinfeld, A., \& Palumbo, R. (2001). Solar thermochemical process technology. Encyclopedia of physical science and technology, 15(1), 237-56.

Ströhle, S., Haselbacher, A., Jovanovic, Z. R., \& Steinfeld, A. (2017). Upgrading sensible-heat storage with a thermochemical storage section operated at variable pressure: An effective way toward active control of the heat-transfer fluid outflow temperature. Applied energy, 196, 51-61. https://doi.org/10.1016/j.apenergy.2017.03.125

Study on methodological aspects regarding limit values for pollutants in aggregates in the context of the possible development of endof-waste criteria under the EU Waste Framework Directive (EU No. 26769). (2014). https://ec.europa.eu/jrc/en/
Van Passel, S., Dubois, M., Eyckmans, J., De Gheldere, S., Ang, F., Tom Jones, P., \& Van Acker, K. (2013). The economics of enhanced landfill mining: Private and societal performance drivers. Journal of Cleaner Production, 55, 92-102. https://doi.org/10.1016/j.jclepro.2012.03.024

Van Vossen, W. J., \& Prent, O. J. (2011). Feasibility study: Sustainable material and energy recovery from landfills in Europe. Proceedings Sardinia 2011, 247-248. Sardinia, Italy.

Winterstetter, A., Laner, D., Rechberger, H., \& Fellner, J. (2015). Framework for the evaluation of anthropogenic resources: A landfill mining case study - Resource or reserve ? 'Resources, Conservation \& Recycling', 96, 19-30. https://doi.org/10.1016/j.resconrec.2015.01.004

Winterstetter, A., Wille, E., Nagels, P., \& Fellner, J. (2018). Decision making guidelines for mining historic landfill sites in Flanders. Waste Management, 77, 225-237. https://doi.org/10.1016/j.wasman.2018.03.049

Wille, E. (2018). Flooding risks at old landfill sites: Linear economy meets climate change. Proceedings of the 4th International Symposium on Enhanced Landfill Mining, 361-365. Mechelen, Belgium

Wolfsberger, T., Aldrian, A., Sarc, R., Hermann, R., Höllen, D., Budischowsky, A., Zöscher, A., Ragoßnig, A., Pomberger, R. (2015). Landfill mining: Resource potential of Austrian landfills - Evaluation and quality assessment of recovered municipal solid waste by chemical analyses. Waste Management \& Research, 33(11) 962-974. https://doi.org/10.1177/0734242X15600051

Yan, J., Huang, Q., Lu, S., Li, X., \& Chi, Y. (2016). Thermal Treatment Techniques: Incineration, Gasification, and Pyrolysis. Sustainable Solid Waste Management, 149-185. https://doi. org/10.1061/9780784414101.ch07

Z'graggen, A., \& Steinfeld, A. (2008). A two-phase reactor model for the steam-gasification of carbonaceous materials under concentrated thermal radiation. Chemical Engineering and Processing: Process Intensification, 47(4), 655-662. 